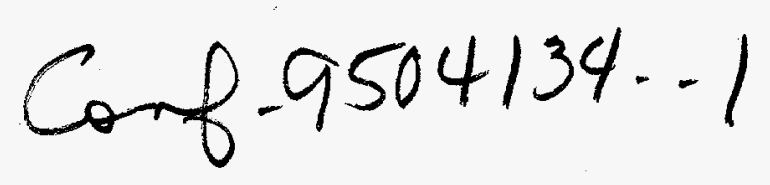

UCRL-JC-118902

PREPRINT

\title{
Treatment of Mixed Waste Coolant
}

\author{
Scott Kidd \\ John S. Bowers \\ This paper was prepared for submittal to \\ HAZMACON 1995 \\ San Josde, CA \\ April 4-6, 1995
}

\section{February 1995}

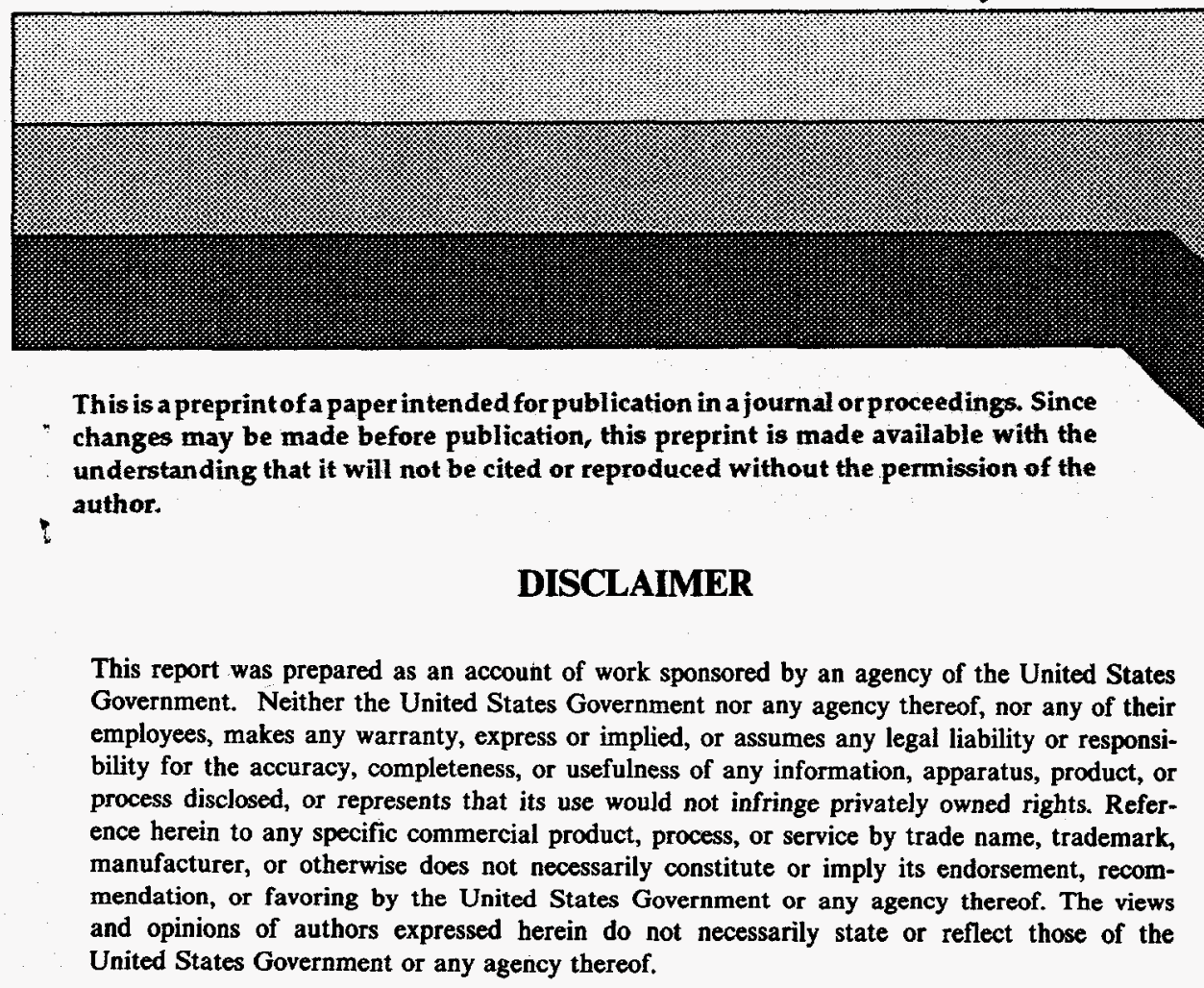




\section{DISCLAIMER}

This document was prepared as an account of work sponsored by an agency of the United States Government. Neither the United States Government nor the University of California nor any of their employees, makes any warranty, express or implied, or assumes any legal liability or responsibility for the accuracy, completeness, or usefulness of any information, apparatus, product, or process disclosed, or represents that its use would not infringe privately owned rights. Reference herein to any specific commercial product, process, or service by trade name, trademark, manufacturer, or otherwise, does not necessarily constitute or imply its endorsement, recommendation, or favoring by the United States Government or the University of California. The views and opinions of authors expressed herein do not necessarily state or reflect those of the United States Government or the University of California, and shall not be used for advertising or product endorsement purposes. 


\section{DISCLAIMER}

Portions of this document may be illegible in electronic image products. Images are produced from the best available original document. 


\title{
TREATMENT OF MIXED WASTE COOLANT
}

\author{
Scott Kidd \\ John S. Bowers \\ Lawrence Livermore National Laboratory \\ Hazardous Waste Management Division \\ Livermore, CA 94550
}

\begin{abstract}
The primary processes used at Lawrence Livermore National Laboratory (LLNL) for treatment of radioactively contaminated machine coolants are industrial waste treatment and in situ carbon adsorption. These two processes simplify approaches to meeting the sanitary sewer discharge limits and subsequent Land Disposal Restriction criteria for hazardous and mixed wastes (40 CFR 268). Several relatively simple technologies are used in industrial water treatment. These technologies are considered "Best Demonstrated Available Technologies," or BDAT, by the Environmental Protection Agency.
\end{abstract}

The machine coolants are primarily aqueous and contain water soluble oil consisting of ethanol amine emulsifiers derived from fatty acids, both synthetic and natural. This emulsion carries away metal turnings from a part being machined on a lathe or other machining tool. When the coolant becomes spent, it contains chlorosolvents carried over from other cutting operations as well as a fair amount of tramp oil from machine bearings. This results in a mutiphasic aqueous waste that requires treatment of metal and organic contaminants.

During treatment, any dissolved metals are oxidized with hydrogen peroxide. Once oxidized, these metals are flocculated with ferric sulfate and precipitated with sodium hydroxide, and then the precipitate is filtered through diatomaceous earth. The emulsion is broken up by acidifying the coolant. Solvents and oils are adsorbed using powdered carbon. This carbon is easily separated from the remaining coolant by vacuum filtration.

\section{INTRODUCTION}

Coolants are a complex form of multilayered heterogeneous waste. At LLNL, the term "coolant" describes waste that is generated in metal cutting. This waste has been considered difficult to treat to meet either land disposal restrictions, National Pollution Discharge Elimination System (NPDES) discharge limits, or both. Because most of the matrix is water, the logical approach is to treat the entire waste stream in an industrial aqueous waste treatment setting using a variety of industrial treatment techniques.

Although there is some diversity in the constituents, the range of contamination, and the original product makeup among coolants, the treatment techniques used are the same.

\section{WASTE STREAM GENERATION AND MAKEUP}

Coolant, as product, is primarily made up of a proprietary emulsion concentrate and water ( $90 \%$ water by volume). The concentrate includes triethanolamine, polyoxyethylene nonionic surface agent, pine oil, dimethyl silicone polymer (antifoam), alkali borate (rust inhibitor), and fungicide and bactericide (phenol derivative). This material is mixed with water to form a $10 \%$ solution by volume. 
An emission spectroscopy performed on the solution yielded the following results:

Table 1. Emission Spectroscopy Results for Raw Coolant Solution.

\begin{tabular}{|l|c|}
\hline \multicolumn{1}{|c|}{ Constituent } & Concentration \\
\hline Boron & $1 \%$ \\
\hline Sodium & $0.2 \%$ \\
\hline Potassium & $0.1 \%$ \\
\hline Silicon & $500 \mathrm{mg} / \mathrm{L}$ \\
\hline Calcium & $300 \mathrm{mg} / \mathrm{L}$ \\
\hline Iron & $100 \mathrm{mg} / \mathrm{L}$ \\
\hline Magnesium & $25 \mathrm{mg} / \mathrm{L}$ \\
\hline Aluminum & $10 \mathrm{mg} / \mathrm{L}$ \\
\hline Copper & $40 \mathrm{mg} / \mathrm{L}$ \\
\hline
\end{tabular}

The coolant is pumped from a reservoir to the metal part that is being machined using a mill or a lathe. The stream of coolant is directed onto the metal part at the tool interface. The coolant's purpose is to sweep away metal turnings as the tool cuts into the part. The coolant also keeps the tool-part interface cool and lubricated. The coolant is recirculated by continually directing the flow of the coolant to the tool interface and allowing the coolant to fall back into the reservoir.

Occasionally, parts are cut using tetrachloroethylene as a coolant such as when parts are made from titanium. Other coolants are used for cutting magnesium, lead, and other metals, because triethanolamine is quite corrosive to these metals.

Other contaminants (methyl chloroform and oil) are found in the coolant. These contaminants are from residues on the metal part or from basic operation and maintenance of the machining equipment. The parts are occasionally degreased with methyl chloroform. The methyl chloroform can carry over into the coolant when the part is placed back on the lathe or mill. Operation and maintenance of the mills and lathes allows for oil (tramp oil) to be deposited into the coolant reservoir.

The coolant is no longer used when it contains too much metal, oil, and or chlorosolvent. After a while, the coolant may also get rancid due to bacterial decay. When the coolant is spent, it is vacuumed up with a wet/dry vacuum or sump sucker and transferred from the reservoir(s) into drums. It is then shipped to the aqueous waste treatment facility for treatment and subsequent disposal.

LLNL composited and sampled approximately 260 drums of spent coolant. The sampling method consisted of using a drum stirrer and mixing the solution for 1 minute to ensure that particulate metals and heavy solvents were representatively mixed into the fluid, then using a long glass tube or a Composite Liquid Waste Sampler (COLIWASA) to collect the material. The samples were analyzed for:

- $\mathrm{pH}$ using a pH electrode

- Percent oil by volume using a graduated cylinder and measuring the phases after settling 
- Organics using EPA SW-846 Methods: 8010, Halogenated Volatile Organics, and 8020, Aromatic Volatile Organics

- Metals using EPA SW-846 Methods: 6010, Inductively Coupled Plasma Atomic Emission Spectroscopy; 7470, Mercury in Liquid Waste/Manual Cold-Vapor Technique; 7061, Arsenic/Atomic Absorption, Gaseous Hydride; and 7741, Selenium/Atomic Absorption, Gaseous Hydride

- Gross alpha and gross beta using approved preparation and counting methods

- Tritium using distillation and scintillation counting.

The results of these test are given below in Table 2 .

Table 2. Analytical Results for Spent Coolant.

\begin{tabular}{|c|c|c|}
\hline Constituent & Concentration & Detection limit \\
\hline $\mathrm{pH}^{*}$ & 9.67 & N/A \\
\hline Percent unemulsified oil & $1 \%$ & N/A \\
\hline Antimony & $<9 \mathrm{mg} / \mathrm{L}$ & $9 \mathrm{mg} / \mathrm{L}$ \\
\hline Arsenic & $0.26 \mathrm{mg} / \mathrm{L}$ & $0.02 \mathrm{mg} / \mathrm{L}$ \\
\hline Barium & $1.4 \mathrm{mg} / \mathrm{L}$ & $0.02 \mathrm{mg} / \mathrm{L}$ \\
\hline Beryllium & $10 \mathrm{mg} / \mathrm{L}$ & $0.02 \mathrm{mg} / \mathrm{L}$ \\
\hline Cadmium & $0.3 \mathrm{mg} / \mathrm{L}$ & $0.1 \mathrm{mg} / \mathrm{L}$ \\
\hline Chromium & $0.51 \mathrm{mg} / \mathrm{L}$ & $0.04 \mathrm{mg} / \mathrm{L}$ \\
\hline Cobalt & $0.2 \mathrm{mg} / \mathrm{L}$ & $0.2 \mathrm{mg} / \mathrm{L}$ \\
\hline Copper & $11 \mathrm{mg} / \mathrm{L}$ & $<0.03 \mathrm{mg} / \mathrm{L}$ \\
\hline Lead & $9.3 \mathrm{mg} / \mathrm{L}$ & $0.6 \mathrm{mg} / \mathrm{L}$ \\
\hline Manganese & $2.1 \mathrm{mg} / \mathrm{L}$ & $0.04 \mathrm{mg} / \mathrm{L}$ \\
\hline Mercury & $<0.06 \mathrm{mg} / \mathrm{L}$ & $0.06 \mathrm{mg} / \mathrm{L}$ \\
\hline Molybdenum & $2.9 \mathrm{mg} / \mathrm{L}$ & $0.03 \mathrm{mg} / \mathrm{L}$ \\
\hline Nickel & $2.1 \mathrm{mg} / \mathrm{L}$ & $<0.05 \mathrm{mg} / \mathrm{L}$ \\
\hline Selenium & $<0.02 \mathrm{mg} / \mathrm{L}$ & $0.02 \mathrm{mg} / \mathrm{L}$ \\
\hline Silver & $0.04 \mathrm{mg} / \mathrm{L}$ & $0.03 \mathrm{mg} / \mathrm{L}$ \\
\hline Thallium & $<0.1 \mathrm{mg} / \mathrm{L}$ & $0.1 \mathrm{mg} / \mathrm{L}$ \\
\hline Vanadium & $0.4 \mathrm{mg} / \mathrm{L}$ & $0.06 \mathrm{mg} / \mathrm{L}$ \\
\hline Zinc & $63 \mathrm{mg} / \mathrm{L}$ & $0.6 \mathrm{mg} / \mathrm{L}$ \\
\hline Tetrachloroethylene & $540 \mathrm{mg} / \mathrm{L}$ & $10 \mathrm{mg} / \mathrm{L}$ \\
\hline Methyl chloroform & $680 \mathrm{mg} / \mathrm{L}$ & $10 \mathrm{mg} / \mathrm{L}$ \\
\hline Gross alpha & $0.107 \mathrm{~Bq} / \mathrm{L}$ & $0.003 \mathrm{~Bq} / \mathrm{L}$ \\
\hline Gross beta & $0.145 \mathrm{~Bq} / \mathrm{L}$ & $0.005 \mathrm{~Bq} / \mathrm{L}$ \\
\hline Tritium & $0.052 \mathrm{~Bq} / \mathrm{L}$ & $0.018 \mathrm{~Bq} / \mathrm{L}$ \\
\hline
\end{tabular}

* $\mathrm{pH}$ by hydronium mass balance 
Mixing is needed to obtain a representative sample of the waste and to reach material that may have settled to the bottom of the tank. Although it may cause some release of volatile constituents (e.g., tetrachloroethylene and methyl chloroform), mixing prevents the problem of not being able to collect sediment at the bottom of the tank, which is a major source of the contamination. The escape of volatiles is minimized by the short mixing duration and by the limited space (two small bung holes in the drum) for molecular diffusion and subsequent release into the atmosphere.

\section{PRINCIPLES USED IN TREATING COOLANTS}

The methods used for removing radionuclides and metals from industrial waste water treatment are usually described as precipitation, flocculation, and filtration. Table 2 shows that antimony, mercury, selenium, and thallium were not found above detection limits, and arsenic was not significantly high. The gross alpha and beta concentration is most likely from natural and depleted uranium. Although some thorium gets machined, compared to uranium, very little of this material is generated. The tritium is not a concern here because it is below what the discharge criteria is for disposal with the Publicly Owned Treatment Waterworks (POTW) NPDES permit.

Organics are usually treated with carbon canisters in the water phase, but this method does not work well for mixed waste. Carbon canisters are not used for the following reasons:

1. A substantial amount of oil in the waste causes frequent saturation of carbon, resulting in added costs for using more canisters.

2. The carbon canister becomes slightly contaminated with radioactivity and prevents costeffective measures for commercially recycling the carbon canisters.

Several principles are used to precipitate industrial waste. The most important are based on:

- Optimizing $\mathrm{pH}$ on metals that are amphoteric in nature

- Increasing solubility by calculating the ionic strengths and reducing the activity coefficient of the solute

- Calculating the oxidation-reduction potential or net potential difference as a function of $\mathrm{pH}$ as in an $\mathrm{pE}-\mathrm{pH}$ (Pourbiax-diagrams) chart and then adjusting the $\mathrm{pH}$ for desired solubility.

Many metals are amphoteric. These metals are weak acids; at low-to-moderate $\mathrm{pH}$, they precipitate out at an optimum $\mathrm{pH}$, and then they become weak bases or form complex hydroxides at an elevated pH. Formation constants and hydroxide solubility product for most common metal hydroxide complexes and precipitates are given in Lange's Handbook of Chemistry. Calculations can be performed using these values to determine the optimum $\mathrm{pH}$ (i.e., the $\mathrm{pH}$ at which the metal is least soluble). These optimum $\mathrm{pH}$ values are given in Table 3 for a few metals. 
Table 3. pH of Lowest Solubility.

\begin{tabular}{|l|c|c|}
\hline Constituent & $\mathbf{p H}$ & $\begin{array}{c}\text { Concentration in (mg/L) at Given pH When } \\
\text { the Activity Coefficients Are Unity }\end{array}$ \\
\hline Beryllium (+2) & 9.2 & 0.0009 \\
\hline Cadmium (+2) & 11.6 & 0.005 \\
\hline Chromium (+3) & 8.0 & 0.004 \\
\hline Copper (+2) & 9.0 & 0.02 \\
\hline Lead (+2) & 10.6 & 16.4 \\
\hline Nickel (+2) & 10.8 & 0.03 \\
\hline $\mathrm{Zinc}(+2)$ & 9.4 & 0.005 \\
\hline $\mathrm{UO}_{2}(+2)$ & 6.2 & $7.1(88 \mathrm{~Bq} / \mathrm{L})$ \\
\hline $\mathrm{PuO}_{2}(+2)$ & 7.8 & $0.00004(91 \mathrm{~Bq} / \mathrm{L})$ \\
\hline
\end{tabular}

Other precipitation techniques are available, but most deal with agents that are more toxic and less environmentally sound than hydroxide. Sulfide salt is a great precipitating agent that is very $\mathrm{pH}$ insensitive and has extremely low solubility products. The difficulty with using sulfide is that it has a low odor threshold, it creates a toxic gas in acidic conditions, and is difficult to disperse in liquid. Nevertheless, it is used as a polishing treatment. As one can see, lead concentrations are high when standard hydroxide precipitation is used.

Ionic strengths of coolant are often high because of the high concentrations of dissolved salts and the type of chemical that is added to the coolant when precipitating metals. Usually activity coefficients cannot be estimated accurately due to high ionic strengths. The DebyeHückel expression cannot be used when the ionic strengths exceed about $0.01 \mathrm{~mol} / \mathrm{L}$. For solutions with moderate ionic strengths, a modification to the Debye-Hückel expression given by Robinson, Guggenheim and Bates can be used. The modified expression can be found in Lange's Handbook of Chemistry and is given below:

$$
\begin{aligned}
& \log f=b l-\frac{A z^{2} \sqrt{1}}{1+B a \sqrt{1}} \\
& f=\text { Activity coefficient } \\
& \mathrm{b}=\text { Constant }(0.2 \text { for water solvent }) \\
& I=\text { Ionic strength } \\
& A=\text { Constant }\left(0.5115 \text { for water, } 25^{\circ} \mathrm{C}\right) \\
& \mathrm{Z}=\text { Valence of the solute } \\
& \mathrm{B}=\text { Constant }\left(0.3291 \text { for water, } 25^{\circ} \mathrm{C}\right) \\
& \mathrm{a}=\text { Ionic radii of the aqueous solute }
\end{aligned}
$$

The activity coefficient calculated for the waste is approximated using sodium sulfate as the primary solute with an ionic strength of $0.081 \mathrm{~mol} / \mathrm{L}$. Using the modified expression, the activity coefficient for the waste is approximately 0.4 . The use of sodium sulfate increases the solubility of the solution by 2.5 because actual solubility is estimated by dividing the ideal solubility by the activity coefficient. 
The behavior of precipitation is influenced by potential differences residing in the waste water in the form of a pE-pH diagram. This is usually measured in industrial waste water by oxidation-reduction potential. This measurement determines if the environment is an oxidizing environment or a reducing environment, which is important because metals have the lowest solubility at the highest oxidation state. The range of potential in water as a function of $\mathrm{pH}$ is valuable to know because it provides an understanding of the environment affected by coolants. Figure 1 shows the stability region for water by plotting electron concentration as a function of $\mathrm{pH}$. The higher the electron concentration, the higher the reduction potential. The lower the electron concentration, the higher the oxidation potential. So, with low electron concentrations, the results yield higher metal oxidation states and lower solubilities.

\section{Figure 1. Water Stability Electron Concentration as a Function of $\mathrm{pH}$.}

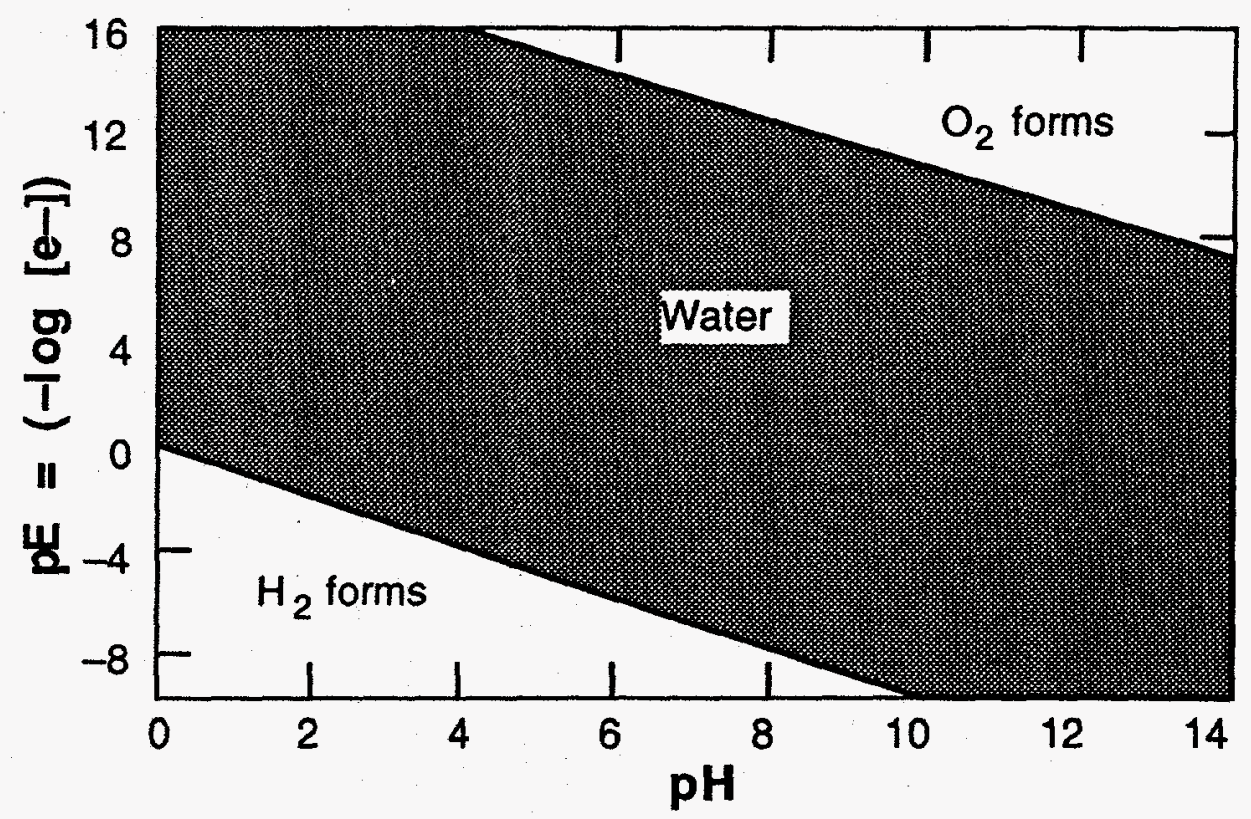

Organics can be treated in the same setting as industrial waste water. Figure 1 also sheds light on ways to deal with organics. If the oxidation potential is high, organics can be broken up into smaller molecules by oxidation. This is practiced by adding oxygen to the coolant in the form of hydrogen peroxide and iron salt (Fenton's Reagent). Organics, even halogenated organics, can be broken up into carbon dioxide and halidic acids by the use of this material. Saturated bonds like those in many oil constituents are also destroyed.

Low-grade activated carbon is used and added to coolant to remove the remaining organics. This is simpler in principle than using columns or adding granular activated carbon because the Freundlich Isotherms for this material apply directly. The low-grade activated carbon is also readily available through carbon manufacturers. For each carbon type, there are two parameters given for each adsorbing species.

These parameters are used in an isotherm equation, presented below:

$$
\mathrm{Q}=\mathrm{KCn}
$$

$\mathrm{Q}=$ Concentration of contaminant on carbon (usually $\mathrm{mg} / \mathrm{g}$ )

$\mathrm{K}=$ Freundlich isotherm parameter

$\mathrm{C}=$ Concentration of contaminant in coolant (usually $\mathrm{mg} / \mathrm{L}$ )

$\mathrm{n}=$ Freundlich isotherm parameter 
An estimate the amount of carbon to add is based on the original constituent concentration and this equation.

\section{SEQUENCE OF TREATMENT}

Once a methodology has been developed based on the principles discussed above, treatment of the coolant waste can begin. In the overall treatment sequence, waste coolant is put into the waste water treatment plant. The waste water treatment plant consists of a rotary-drum vacuum-filter (RDVF) unit and several 7000-L (1,850-gal) capacity tanks that are equipped with stirrers.

The coolant is placed into a tank and mixed. The coolant $\mathrm{pH}$ is dropped to about 3.0 by adding sulfuric acid. This breaks up coolant emulsion and facilitates the oxidation reaction to follow. Hydrogen peroxide is added to the coolant, which raises the oxidation states of all the metals and breaks up the oil and organic film.

At this point, you can detect oxygen and carbon dioxide gases being emitted from the solution. Foaming occurs at this stage, but it is not substantial and often subsides during filtration. Ferric sulfate is added after hydrogen peroxide. The ferric sulfate serves as a flocculant and destabilizes the charge around the precipitate that will be formed later.

The coolant now has very little oil on its surface. Precipitates form as the orange color caused by the ferric sulfate swirls around the tank. These precipitates are saturated sulfate salts. In many cases, sulfates have low solubility but low not enough to preclude hydroxide precipitation. After mixing the tank for several minutes, sodium hydroxide is added to precipitate the metals. Usually the precipitation will be carried out at a $\mathrm{pH}$ of 9.0 , but high radioactivity concentrations are reduced more efficiently at higher a $\mathrm{pH}$ (usually around 12).

Once the sodium hydroxide has been added to the coolant, the solution is allowed to mix for at least 20 minutes. During this time, valves are lined up to route the tank contents to the RDVF. After performing the valve line up, carbon is added to the coolant solution. The carbon adsorbs the remaining organic constituents and is filtered out along with the precipitates. The filter used in the RDVF system to trap the spent carbon and precipitates is a diatomaceous earth media. The filter cake residue (i.e., diatomaceous earth, spent carbon, and precipitates) is cut off the rotary filtration drum and stored for further stabilization.

The effluent leaves the filter clear and relatively colorless. If metals such as lead, radionuclides, or other contaminants are still present at unacceptable levels, the waste is treated again. If the constituents are low enough in concentration, sulfide will be used as a polishing treatment.

\section{RESULTS}

Table 4 shows typical before and after treatment analysis. The analyses were performed using the Environmental Protection Agency's Test Methods for Evaluating Solid Waste, Physical/Chemical Methods (EPA publication SW-846). For these particular samples, organic concentrations were lower than the composite given in Table 2. Organic concentrations before treatment and after one or more treatments are given in Figure 2. Data reported in Figure 2 are for organics that can be extracted by Freon 113. 
Table 4. pH of Lowest Solubility.

\begin{tabular}{|c|c|c|c|c|c|c|c|c|}
\hline Type & $\begin{array}{c}\text { Before } \\
\text { Treat }\end{array}$ & $\begin{array}{l}\text { After } \\
\text { Treat }\end{array}$ & $\begin{array}{c}\text { Before } \\
\text { Treat }\end{array}$ & $\begin{array}{l}\text { After } \\
\text { Treat }\end{array}$ & $\begin{array}{c}\text { Before } \\
\text { Treat }\end{array}$ & $\begin{array}{l}\text { After } \\
\text { Treat }\end{array}$ & $\begin{array}{c}\text { Before } \\
\text { Treat }\end{array}$ & $\begin{array}{l}\text { After } \\
\text { Treat }\end{array}$ \\
\hline Batch Number & $92-06$ & $92-06$ & $92-07$ & $92-07$ & $92-13$ & $92-13$ & $92-16$ & $92-16$ \\
\hline Sample No. & 9103001 & 9200025 & 9200169 & 9200165 & 9200563 & 9200626 & 9200662 & 9200738 \\
\hline Liters & 4901 & 5046 & 5046 & 5046 & 4685 & 5118 & 4974 & 5046 \\
\hline \multicolumn{9}{|c|}{ CAM-WET Metals in mg/L (ppm) } \\
\hline Antimony & $<0.6$ & $<0.6$ & $<0.6$ & $<0.6$ & 0.800 & $<0.9$ & $<0.9$ & $<0.8$ \\
\hline Arsenic & 0.020 & 0.050 & ND & 0.007 & 0.006 & $<0.001$ & 0.010 & 0.005 \\
\hline Barium & 4.500 & 0.520 & 10.000 & 0.052 & 0.120 & 0.010 & 0.120 & 0.006 \\
\hline Beryllium & 1.800 & 0.089 & 0.190 & $<0.003$ & 0.066 & $<0.004$ & 0.020 & $<0.004$ \\
\hline Cadmium & 0.100 & $<0.02$ & 0.040 & $<0.02$ & 0.760 & $<0.02$ & 0.360 & $<0.03$ \\
\hline Chromium & 17.000 & 4.200 & 0.770 & 0.230 & 16.000 & 0.730 & 5.400 & 1.000 \\
\hline Cobalt & 0.090 & 0.100 & 0.070 & 0.050 & 0.500 & 0.040 & 0.440 & $<0.03$ \\
\hline Copper & 36.000 & 16.000 & 4.200 & 0.670 & 34.000 & 0.057 & 24.000 & 0.096 \\
\hline Lead & 9.700 & 0.500 & 0.880 & $<0.04$ & 2.300 & $<0.05$ & 1.700 & 0.060 \\
\hline Manganese & 6.100 & 0.490 & 0.890 & $<0.006$ & 7.700 & $<0.006$ & 1.300 & 0.007 \\
\hline Mercury & 2.200 & 0.410 & 0.160 & $<0.005$ & 0.049 & $<0.003$ & 0.006 & $<0.003$ \\
\hline Molybdenum & 0.440 & 0.630 & 0.290 & 0.350 & 1.900 & 1.000 & 3.200 & 2.000 \\
\hline Nickel & 9.600 & 4.600 & 1.100 & 0.500 & 340.000 & \begin{tabular}{|l|}
0.420 \\
\end{tabular} & 63.000 & 0.120 \\
\hline Selenium & $<0.001$ & 0.006 & ND & $<0.002$ & $<0.001$ & 0.033 & 0.003 & 0.100 \\
\hline Silver & 2.500 & 0.350 & 0.110 & $<0.005$ & 2.800 & 0.010 & 0.079 & $<0.006$ \\
\hline Thallium & 0.030 & $<0.01$ & $<0.01$ & $<0.02$ & 0.720 & $<0.01$ & $<0.01$ & $<0.02$ \\
\hline Vanadium & 0.490 & 0.440 & 0.110 & 0.088 & 0.910 & \begin{tabular}{|l|}
0.250 \\
\end{tabular} & 0.640 & 0.040 \\
\hline Zinc & 8.200 & 0.900 & 20.000 & 0.300 & 9.600 & $<0.07$ & 4.600 & 0.100 \\
\hline \multicolumn{9}{|l|}{ RAD ANALYSIS } \\
\hline alpha $(\mu \mathrm{Ci} / \mathrm{ml})$ & $3.70 \mathrm{E}-04$ & $5.40 \mathrm{E}-05$ & $1.30 \mathrm{E}-05$ & ND & $2.10 \mathrm{E}-06$ & ND & $1.20 \mathrm{E}-07$ & ND \\
\hline beta $(\mu \mathrm{Ci} / \mathrm{ml})$ & $3.00 \mathrm{E}-05$ & $2.00 \mathrm{E}-05$ & $6.80 \mathrm{E}-06$ & $3.10 \mathrm{E}-07$ & $2.10 \mathrm{E}-06$ & ND & $\mathrm{ND}$ & ND \\
\hline tritium $(\mu \mathrm{Ci} / \mathrm{ml})$ & $2.00 \mathrm{E}-04$ & $1.80 \mathrm{E}-04$ & $2.10 \mathrm{E}-05$ & $2.70 \mathrm{E}-05$ & $2.80 \mathrm{E}-05$ & $2.10 \mathrm{E}-05$ & $6.30 \mathrm{E}-06$ & $5.10 \mathrm{E}-06$ \\
\hline
\end{tabular}


Figure 2. Organic Concentrations Before and After Treatment(s)

Freon Extractable Organics

Each line represents a different batch

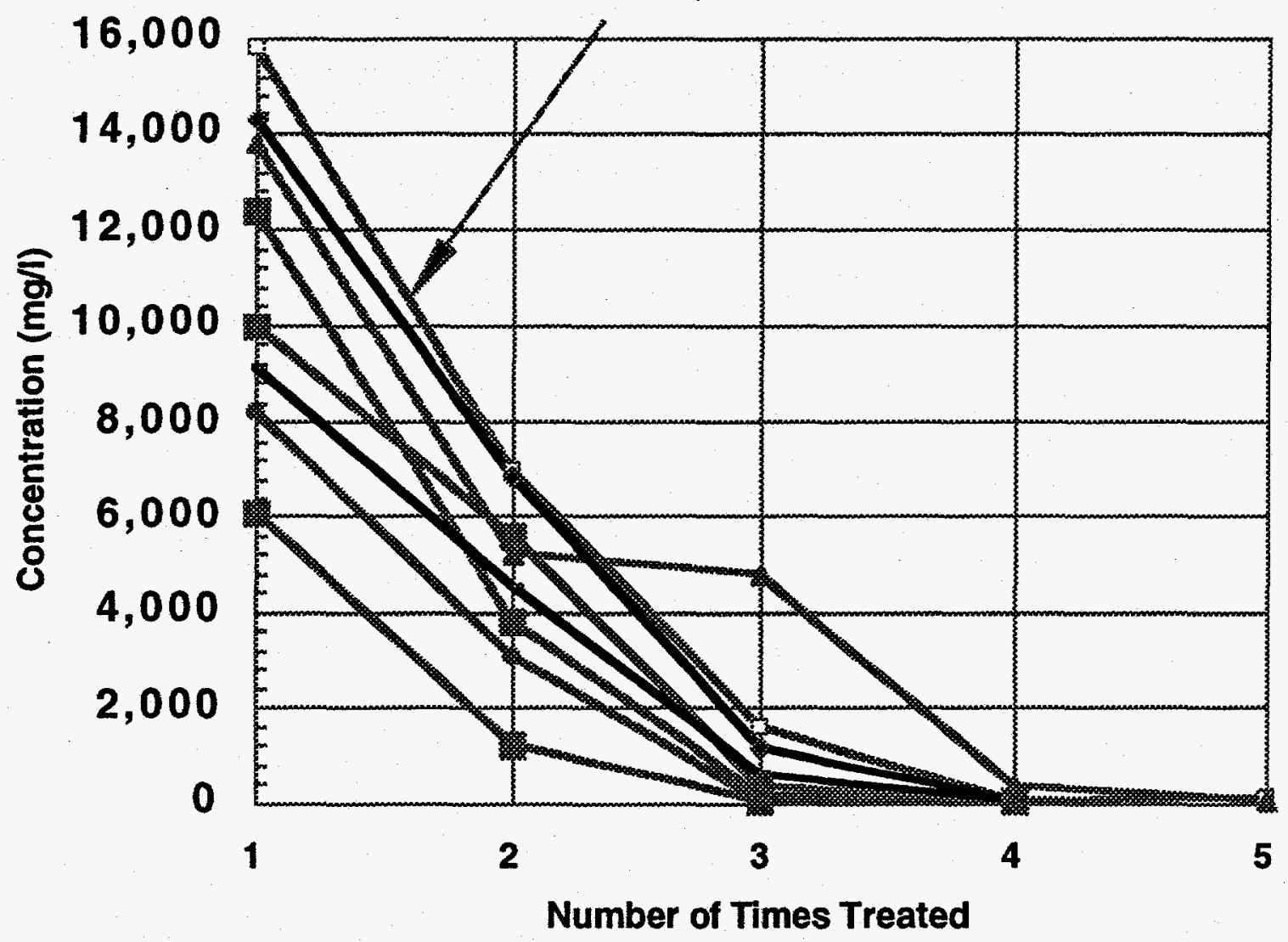

\section{CLOSING STATEMENT}

Radioactive waste coolants can be treated successfully with industrial waste water methods by applying the principles of $\mathrm{pH}$ optimization, ionic strength, oxidation-reduction potential, and carbon adsorption principles.

\section{ACKNOWLEDGEMENT}

Work performed under the auspices of the U.S. Department of Energy by Lawrence Livermore National Laboratory under Contract W-7405-ENG-48. 